\title{
Analisis sumbangan materi hidrokarbon terhadap keterampilan berpikir kritis siswa kelas XI MIA Tahun Ajaran 2018/2019 di SMAN 1 Lawang
}

\author{
Reza Rewindi Amayliadevi, Herunata*, Hayuni Retno Widarti \\ Universitas Negeri Malang, Jl. Semarang No. 5 Malang, Jawa Timur, Indonesia \\ *Penulis korespondensi, Surel: herunata.fmipa@um.ac.id
}

Paper received: 01-06-2021; revised: 15-06-2021; accepted: 30-06-2021

\begin{abstract}
In the 21st century, students need to have one of life skill that is critical thinking that can be develop and trained through various aspects and one of which is chemistry aspect. One of the materials in the chemistry aspect is a hydrocarbon material. The purpose of this study was to measure the percentage of hydrocarbon contribution towards student's critical thinking skills and to know the level of critical thinking skills in 11th MIA grade students 2018/2019 academic year at SMAN 1 Lawang. The study used a descriptive quantitative research design. The research subjects which amount to 133 students. Instrument for assessing critical thinking skills used in hydrocarbon material developed by Rodliyah (2018) with critical thinking indicators Ennis (2011). The results of the analysis of the level of critical thinking skills of students using the number of students who scored three on reasoned multiple choice questions and score four on the description questions divided by the total number of sample students, then categorized by percentage according to Karim (2015). The results showed that the hydrocarbon material taught by the teacher was able to bring up the students' critical thinking skills with a level of think critically which was still very low with an average of 1) organic and inorganic carbon compounds by 39.10 percent, 2) identification and source of carbon compounds by 13.53 percent, 3) specificity of carbon atoms by 27.82 percent, 4) nomenclature of hydrocarbon compounds by 16.29 percent, 5 ) isomer hydrocarbon compounds by 9.62 percent, 6) physical and chemical properties of hydrocarbons by 29.32 percent for the subject matter of the physical properties of hydrocarbons, the subject matter of the hydrocarbon compound combustion reaction by 5.71 percent, the subject of substitution reactions alkane compounds by 0.94 percent, the subject matter of the reaction of alkene compounds by 11.58 percent, the subject matter of the reaction of alkaline compounds by 3.57 percent, and the subtopics of identification were saturated and unsaturated hydrocarbons by 0.75 percent, and 7) the use of hydrocarbons by 14.43 percent.
\end{abstract}

Keywords: analysis; contribution; hydrocarbons; critical thinking skills

Abstrak
Salah satu kecakapan hidup yang harus dimiliki siswa pada abad 21 adalah keterampilan berpikir
kritis yang dapat dikembangkan dan dilatih melalui beragam bidang, salah satunya adalah bidang
kimia yaitu pada materi hidrokarbon. Tujuan penelitian ini mengukur persentase sumbangan
materi hidrokarbon terhadap kemampuan keterampilan berpikir kritis siswa dan mengetahui
tingkat kemampuan keterampilan berpikir kritis siswa kelas XI MIA tahun ajaran $2018 / 2019$ di
SMAN 1 Lawang. Penelitian menggunakan rancangan penelitian kuantitatif deskriptif dengan
subjek penelitian 133 siswa. Instrumen penilaian keterampilan berpikir kritis yang digunakan pada
materi hidrokarbon yang dikembangkan oleh Rodliyah (2018) dengan indikator berpikir kritis
Ennis (2011). Data berupa skor 3 pada soal pilihan ganda beralasan dan skor 4 pada soal uraian
yang telah diperoleh dianalisis sesuai dengan pengelompokkan pokok bahasan pada materi
hidrokarbon lalu dikategorikan berdasarkan jumlah persentase menurut Karim (2015). Hasil
penelitian menunjukkan bahwa materi hidrokarbon yang diajarkan oleh guru mampu
memunculkan kemampuan keterampilan berpikir kritis siswa dengan tingkat kemampuan
keterampilan berpikir kritis yang masih tergolong sangat rendah dengan rata-rata antara lain 1 )
senyawa karbon organik dan anorganik sebesar 39,10 persen, 2) identifikasi dan sumber senyawa
karbon sebesar 13,53 persen, 3) kekhasan atom karbon sebesar 27,82 persen, 4) tata nama

This work is licensed under a Creative Commons Attribution-ShareAlike 4.0 International License. 
senyawa hidrokarbon sebesar 16,29 persen, 5) isomer senyawa hidrokarbon sebesar 9,62 persen, 6) sifat fisika dan kimia senyawa hidrokarbon pada sub pokok bahasan sifat fisika senyawa hidrokarbon sebesar 29,32 persen, sub pokok bahasan reaksi pembakaran senyawa hidrokarbon sebesar 5,71 persen, sub pokok bahasan reaksi substitusi senyawa alkana sebesar 0,94 persen, sub pokok bahasan reaksi senyawa alkena sebesar 11,58 persen, sub pokok bahasan reaksi senyawa alkuna sebesar 3,57 persen, dan sub pokok bahasan identifikasi senyawa hidrokarbon jenuh dan tak jenuh sebesar 0,75 persen, dan 7) kegunaan senyawa hidrokarbon sebesar 14,43 persen.

Kata kunci: analisis; sumbangan; hidrokarbon; keterampilan berpikir kritis

\section{Pendahuluan}

Seiring dengan adanya perkembangan zaman dan teknologi baik di bidang informasi maupun komunikasi berdampak pada sistem pendidikan, dimana dituntut untuk dapat meningkatkan kualitas pendidikan karakter guna mempersiapkan sumber daya manusia yang berkompeten untuk menghadapi abad ke-21. Akan tetapi, hasil Programme for International Student Assessment (PISA) tahun 2015 menunjukkan bahwa pada bidang sains Indonesia berada di peringkat kesembilan paling akhir dengan hasil nilai rata-rata PISA 2015 yaitu 403, sedangkan pada bidang membaca berada pada peringkat ketujuh dengan hasil nilai rata-rata yaitu 397 (OECD, PISA 2015 Database). Berpikir kritis merupakan kecakapan bernalar dan berpikir reflektif yang berpusat untuk memutuskan hal-hal apa yang meyakinkan untuk dipercaya atau dilakukan (Ennis, 2011). Keterampilan berpikir kritis dapat dikembangkan dan dilatih melalui beragam bidang, salah satunya adalah bidang kimia.

Salah satu materi pada bidang kimia adalah materi hidrokarbon. Sebagian besar siswa menganggap bahwa materi hidrokarbon berisi pengetahuan informatif yang berisi hafalan. Namun, penilaian pada materi hidrokarbon tidak hanya ditekankan pada hafalan saja karena materi tersebut dapat ditekankan pada pertanyaan yang membutuhkan kajian lebih mendalam dan pemikiran yang kritis. Keterampilan berpikir kritis pada materi hidrokarbon dapat dikembangkan dengan adanya permasalahan kontekstual dalam kehidupan sehari-hari yang digunakan sebagai stimulus agar siswa mampu memiliki alur berpikir yang kritis.

Berpikir kritis merupakan salah satu keterampilan berpikir yang tidak didapatkan oleh siswa secara langsung sejak lahir. Diperlukan adanya latihan pada saat proses pembelajaran supaya keterampilan berpikir kritis dapat berkembang. Selain itu, penelitian yang dilakukan oleh Pambudiono dkk (2013) menunjukkan bahwa keterampilan berpikir kritis pada beberapa Sekolah Menengah Atas (SMA) di Kota Malang belum sepenuhnya diberdayakan. Peneliti lainnya yaitu Yustyan dkk (2015) menyatakan bahwa kebanyakan sekolah memiliki kondisi pembelajaran yang belum dapat mendukung keefektifan pelaksanaan pembelajaran keterampilan berpikir kritis. Menurut pengalaman Kajian dan Praktek Lapangan (KPL) yang dimulai pada bulan Agustus 2018 peneliti di tempat yang telah dipilih sebagai tempat penelitian juga belum sepenuhnya memberdayakan upaya untuk meningkatkan keterampilan berpikir kritis siswa. Adanya konsep-konsep yang dianggap sulit oleh siswa menjadikan beberapa siswa cenderung pasif pada saat proses pembelajaran berlangsung. Salah satu bentuk kepasifan siswa yaitu keinginan bertanya yang rendah sehingga siswa cenderung diam meskipun sudah diberikan stimulus oleh guru untuk meminta siswa berpendapat. Keterampilan berpikir kritis pada siswa perlu diidentifikasi dan dianalisis guna dijadikan acuan untuk mencari sebuah upaya yang bisa dilakukan dalam meningkatkan keterampilan berpikir kritis siswa. 
Macam-macam indikator keterampilan berpikir kritis menurut Ennis (2011) yaitu memberikan penjelasan sederhana, membangun keterampilan dasar, mengemukakan kesimpulan/inferensi, memberikan penjelasan lebih lanjut, memperkirakan dan mengintegrasikan pada materi hidrokarbon telah diimplementasikan dalam bentuk buku soal instrumen penilaian keterampilan berpikir kritis pada materi hidrokarbon oleh Rodliyah (2018). Penelitian ini dilakukan untuk mengukur persentase sumbangan materi hidrokarbon terhadap keterampilan berpikir kritis dan mengetahui tingkat keterampilan berpikir kritis siswa XI MIA tahun ajaran 2018/2019 pada materi hidrokarbon di SMAN 1 Lawang, serta sebagai pembuktian secara empiris atas tersedianya buku soal instrumen tersebut dengan cara mengaplikasikannya karena pada penelitian sebelumnya hanya dalam bentuk buku soal sehingga belum teruji secara empiris.

\section{Metode}

Rancangan penelitian yang digunakan pada penelitian adalah rancangan penelitian kuantitatif deskriptif. Penelitian ini dilakukan untuk mengukur persentase sumbangan materi hidrokarbon terhadap keterampilan berpikir kritis dan mengetahui tingkat keterampilan berpikir kritis siswa kelas XI MIA tahun ajaran 2018/2019 pada materi hidrokarbon di SMAN 1 Lawang. Subjek penelitian yang digunakan pada penelitian berjumlah 133 siswa sampel yang memiliki kriteria yaitu siswa dalam kelas tersebut telah memperoleh pembelajaran materi hidrokarbon pada semester ganjil tahun ajaran 2018/2019 yang dibelajarkan oleh guru kimia masing-masing. Peneliti membuat kuis dengan tipe soal keterampilan berpikir kritis yang mencakup beberapa subindikator keterampilan berpikir kritis pada beberapa pokok bahasan hidrokarbon sebagai latihan siswa untuk persiapan tes tulis mengerjakan instrumen penilaian keterampilan berpikir kritis.

Pengumpulan data yang dilakukan pada penelitian ini dengan cara melakukan tes tulis pada kelas sampel terkait materi yang digunakan yaitu materi hidrokarbon dengan menggunakan instrumen penilaian keterampilan berpikir kritis. Instrumen tes yang digunakan telah dikembangkan oleh Rodliyah (2018) yang mendapatkan kategori sangat layak digunakan karena telah valid dan reliabel. Instrumen penilaian terdiri dari 25 butir soal pilihan ganda beralasan yaitu terdiri dari 5 opsi pilihan jawaban disertai alasan terbuka mengapa siswa memilih opsi tersebut pada bagian A (tipe soal pilihan ganda) dan 9 butir soal yang dijabarkan menjadi 19 poin butir soal uraian pada bagian B (tipe soal uraian). Instrumen penilaian ini dikerjakan oleh siswa dengan waktu 135 menit atau setara dengan 3 jam pelajaran. Selanjutnya, dilakukan pengamatan dan analisis terhadap hasil jawaban siswa sampel penelitian yang dapat digunakan sebagai data pendukung dari hasil tes tulis yang telah dilakukan.

Analisis data yang dilakukan pada penelitian ini dilakukan dengan mengoreksi jawaban siswa pada bagian A dan B. Tahap koreksi jawaban siswa ini sekaligus pemberian skor sesuai dengan kriteria yang ada pada instrumen penilaian keterampilan berpikir kritis yang digunakan. Persentase nilai siswa pada tiap poin soal bagian A dan B dihitung berdasarkan skor yang diperoleh siswa. Penentuan persentase pada setiap pokok bahasan dan sub pokok bahasan yang diperoleh oleh masing-masing siswa dapat dihitung dengan rumus sebagai berikut. 
Nilai Persentase $=\frac{\text { Jumlah siswa yang mendapat skor maksimal }}{\text { Jumlah siswa sampel secara keseluruhan }} \times 100 \%$

Kemudian, tiap-tiap soal dikelompokkan berdasarkan pokok bahasan atau materi hidrokarbonnya dan diidentifikasi kategori aspek keterampilan berpikir kritisnya. Selanjutnya, ditentukan persentase pada setiap pokok bahasan dan sub pokok bahasan yang diperoleh oleh masing-masing siswa dan ditentukan tingkat keterampilan berpikir kritis siswa dengan menggunakan kriteria yang telah diadaptasi dari Karim (2015) yang disajikan dalam Tabel 1.

Tabel 1 Kategori penentuan tingkat keterampilan berpikir kritis siswa

\begin{tabular}{ll}
\hline Persentase & Kategori \\
\hline $0<$ Nilai $\leq 43,75$ & Sangat Rendah \\
$43,75<$ Nilai $\leq 62,50$ & Rendah \\
$62,50<$ Nilai $\leq 71,50$ & Cukup \\
$71,50<$ Nilai $\leq 81,25$ & Tinggi \\
$81,25<$ Nilai $\leq 100,00$ & Sangat Tinggi \\
\hline
\end{tabular}

Sumber: Diadaptasi dari Karim (2015)

\section{Hasil dan Pembahasan}

Berdasarkan data hasil tes yang dilakukan pada penelitian ini menunjukkan bahwa sebagian besar pokok bahasan materi senyawa hidrokarbon yang dibelajarkan oleh guru, secara tidak langsung telah memunculkan keterampilan berpikir kritis yang diperoleh siswa. Data hasil penelitian dianalisis sesuai dengan pokok bahasan di atas dengan subindikator keterampilan berpikir kritis menurut Ennis (2011) meliputi: (1) memfokuskan pertanyaan, (2) menganalisis argumen, (3) bertanya dan menjawab pertanyaan yang membutuhkan penjelasan, (4) menilai kredibilitas suatu sumber, (5) mengobservasi dan mepertimbangkan hasil observasi, (6) mendeduksi dan menilai hasil deduksi, (7) membuat induksi, (8) membuat dan menilai pembuatan keputusan, (9) mendefinisikan istilah-istilah dan menilai definisi menggunakan kriteria yang sesuai (mempertimbangkan 3 dimensi; bentuk fungsi dan isi), (10) menguraikan asumsi yang tidak dinyatakan, (11) mengintegrasikan sikap dan kemampuan lain, serta (12) pemikiran yang benar.

Analisis data penelitian ini didasarkan pada persentase keterampilan berpikir kritis yang dimiliki siswa dihitung dari jumlah siswa yang menjawab benar dengan alasan benar pada soal pilihan ganda beralasan sehingga memperoleh skor 3 dan menjawab dengan benar sesuai dengan kriteria pada soal uraian dan memperoleh skor 4 yang disajikan pada Gambar 1. 


\section{Gambar 1 Grafik Persentase Keterampilan Berpikir Kritis Siswa pada Materi Hidrokarbon}

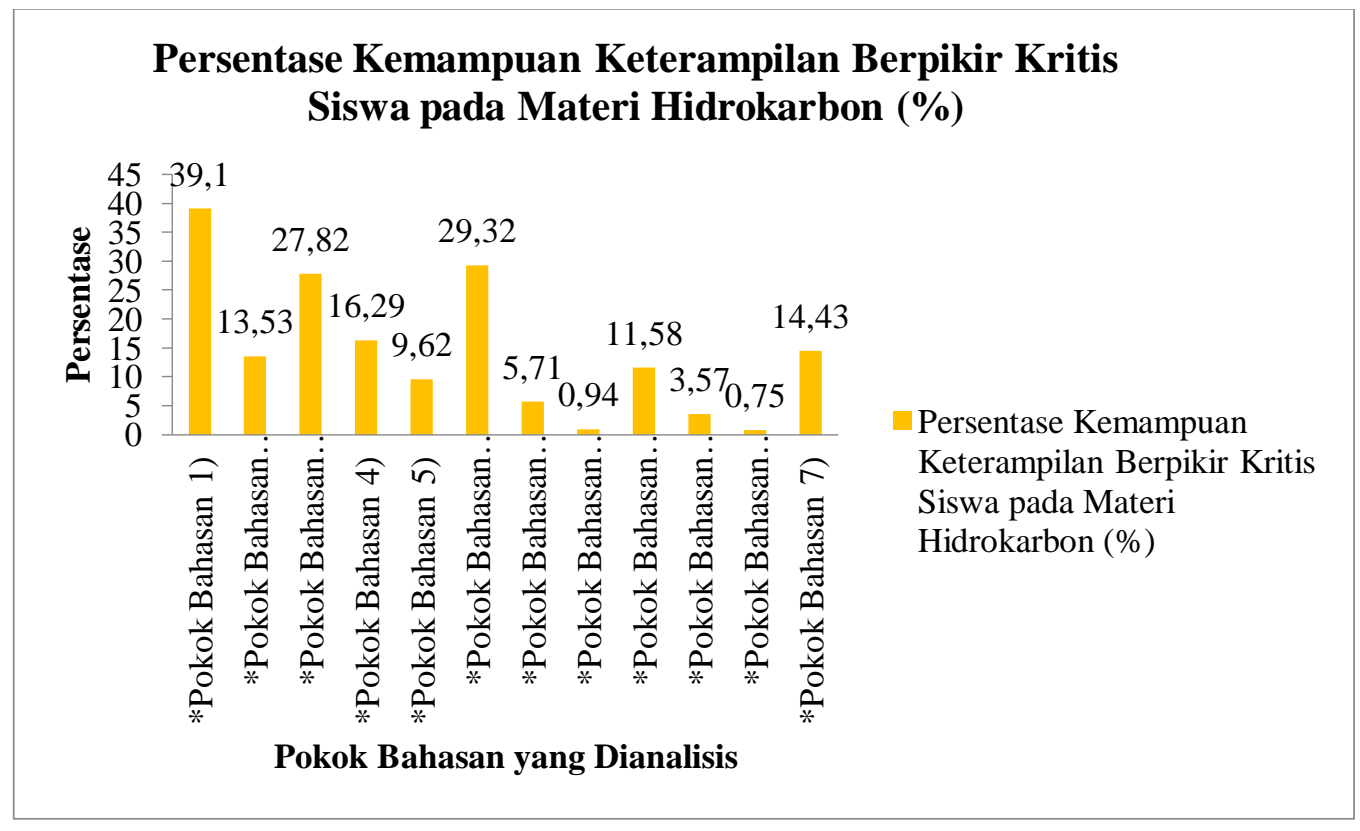

Pokok bahasan 1 terkait senyawa karbon organik dan anorganik, pokok bahasan 2 terkait identifikasi dan sumber senyawa karbon, pokok bahasan 3 terkait kekhasan atom karbon, pokok bahasan 4 terkait tata nama senyawa hidrokarbon, pokok bahasan 5 terkait isomer senyawa hidrokarbon, pokok bahasan 6.1 terkait sifat fisika senyawa hidrokarbon, pokok bahasan 6.2 terkait reaksi pembakaran senyawa hidrokarbon, pokok bahasan 6.3 terkait reaksi substitusi senyawa alkana, pokok bahasan 6.4 terkait reaksi senyawa alkena, pokok bahasan 6.5 terkait reaksi senyawa alkuna, pokok bahasan 6.6 terkait identifikasi senyawa hidrokarbon jenuh dan tak jenuh, dan pokok bahasan 7 terkait kegunaan senyawa hidrokarbon.

Berdasarkan data hasil tes siswa dalam mengerjakan instrumen keterampilan berpikir kritis pada materi senyawa hidrokarbon menunjukkan bahwa keterampilan berpikir kritis yang dimiliki siswa XI MIA di SMAN 1 Lawang tahun ajaran 2018//2019 pada materi ini termasuk ke dalam kategori sangat rendah. Secara umum, alur berpikir siswa dapat dianalisis berdasarkan jawaban yang diberikan siswa. Kelebihan dari penggunaan soal pilihan ganda beralasan dan uraian mencakup tentang bagaimana siswa mampu mengolah pikirannya untuk mengemukakan jawaban yang tepat dan sesuai dengan konsep yang telah diperoleh siswa. Menurut Kuswana dalam Kartimi dkk (2012), keterampilan berpikir kritis berhubungan dengan tingkat kecerdasan. Keterampilan berpikir kritis tidak serta-merta diperoleh siswa, diperlukan adanya penggabungan antara kecerdasan dan kreatifitas siswa untuk memperoleh keterampilan ini. Materi hidrokarbon yang dapat menyumbangkan keterampilan berpikir kritis siswa memuat beberapa pokok bahasan seperti yang tertera pada Gambar 1.

Pokok bahasan senyawa organik dan anorganik yang diajarkan oleh guru kimia SMA termasuk ke dalam pengetahuan faktual yang membahas tentang perbedaan senyawa karbon organik dan anorganik jika dilihat dari struktur dan sifatnya. Materi perbedaan senyawa karbon organik dan anorganik yang telah diajarkan oleh guru ternyata mampu memunculkan salah satu aspek indikator dari keterampilan berpikir kritis yaitu indikator 
memberikan penjelasan sederhana. Hal tersebut dibuktikan dengan hasil tes yang telah dilakukan menunjukkan data sebanyak 52 siswa dengan persentase 39,10\% dari keseluruhan siswa dapat menjawab soal dengan opsi pilihan dan alasan yang tepat dan kritis.

Pokok bahasan mengenai identifikasi dan sumber senyawa karbon yang diajarkan oleh guru kimia SMA membahas tentang bagaimana mengidentifikasi apakah suatu senyawa tersebut mengandung unsur karbon dengan cara membakar senyawa yang diuji. Materi identifikasi dan sumber senyawa karbon yang telah diajarkan oleh guru ternyata mampu memunculkan salah satu aspek indikator dari keterampilan berpikir kritis yaitu indikator memberikan penjelasan sederhana. Hal tersebut dibuktikan dengan hasil tes yang telah dilakukan menunjukkan data sebanyak 18 siswa dengan persentase 13,53\% dari keseluruhan siswa dapat menjawab soal dengan opsi pilihan dan alasan yang tepat dan kritis.

Pokok bahasan mengenai kekhasan atom karbon yang diajarkan oleh guru kimia SMA membahas tentang konfigurasi elektron atom karbon, cara atom karbon berikatan, dan posisi atom karbon di dalam rantai karbon. Materi kekhasan atom karbon yang telah diajarkan oleh guru ternyata mampu memunculkan salah satu aspek indikator dari keterampilan berpikir kritis yaitu indikator memberikan penjelasan sederhana. Hal tersebut dibuktikan dengan hasil tes yang dilakukan menunjukkan data sebanyak 37 siswa dengan persentase 27,82\% dari keseluruhan siswa dapat menjawab soal dengan opsi pilihan dan alasan yang tepat dan kritis.

Pokok bahasan mengenai tata nama senyawa hidrokarbon merupakan salah satu pokok bahasan yang paling sering dibahas dalam materi hidrokarbon yang membahas tentang pemberian nama senyawa hidrokarbon yaitu alkana, alkena, dan alkuna berdasarkan aturan IUPAC (International Union and Pure Applied Chemistry). Materi tata nama senyawa hidrokarbon yang telah diajarkan oleh guru kimia SMA mampu memunculkan beberapa aspek indikator dari keterampilan berpikir kritis yaitu indikator a) memberikan penjelasan sederhana, b) mengemukakan kesimpulan/inferensi, c) memberikan penjelasan lebih lanjut, dan d) memperkirakan dan mengintegrasikan. Hal tersebut dibuktikan dengan hasil tes yang telah dilakukan menunjukkan persentase $16,29 \%$ dari keseluruhan siswa dapat menjawab soal dengan benar dan alasan yang tepat dan kritis.

Pokok bahasan mengenai isomer senyawa hidrokarbon yang diajarkan oleh guru kimia SMA membahas tentang definisi isomer, isomer kerangka/rantai, isomer posisi, dan isomer cis-trans. Ketika guru mengajarkan materi isomer senyawa hidrokarbon kepada siswa, ternyata hal tersebut mampu memunculkan beberapa aspek indikator dari keterampilan berpikir kritis yaitu indikator a) memberikan penjelasan sederhana, b) memberikan penjelasan lebih lanjut, dan c) memperkirakan dan mengintegrasikan. Hal tersebut dibuktikan dengan hasil tes yang telah dilakukan menunjukkan persentase 9,62\% dari keseluruhan siswa dapat menjawab soal dengan benar dan alasan yang tepat dan kritis.

Pokok bahasan mengenai sifat fisika dan sifat kimia hidrokarbon dengan sub pokok bahasan sifat fisika senyawa hidrokarbon ternyata mampu memunculkan keterampilan kritis siswa ketika sifat fisika senyawa hidrokarbon dibelajarkan kepada siswa. Materi sifat fisika senyawa hidrokarbon yang telah diajarkan oleh guru kimia SMA mampu memunculkan beberapa aspek indikator dari keterampilan berpikir kritis yaitu indikator a) memberikan penjelasan sederhana, b) mengemukakan kesimpulan/inferensi, dan c) memberikan penjelasan lebih lanjut. Hal tersebut dibuktikan dengan hasil tes yang telah dilakukan 
menunjukkan persentase 29,32\% dari keseluruhan siswa dapat menjawab soal dengan benar dan alasan yang tepat dan kritis.

Pokok bahasan mengenai sifat fisika dan sifat kimia hidrokarbon dengan sub pokok bahasan reaksi pembakaran pada senyawa hidrokarbon yang telah diajarkan oleh guru kimia SMA mampu memunculkan beberapa aspek indikator dari keterampilan berpikir kritis. Beberapa aspek indikator tersebut yaitu indikator a) memberikan penjelasan sederhana, b) mengemukakan kesimpulan/inferensi, dan c) memberikan penjelasan lebih lanjut. Hal tersebut dibuktikan dengan hasil tes yang telah dilakukan menunjukkan persentase 5,71\% dari keseluruhan siswa dapat menjawab soal dengan benar dan alasan yang tepat dan kritis.

Pokok bahasan mengenai sifat fisika dan sifat kimia hidrokarbon dengan sub pokok bahasan reaksi substitusi senyawa alkana yang telah diajarkan oleh guru kimia SMA mampu memunculkan beberapa aspek indikator dari keterampilan berpikir kritis. Beberapa aspek indikator dari keterampilan berpikir kritis yaitu indikator a) memberikan penjelasan sederhana, b) mengemukakan kesimpulan/inferensi, c) memperkirakan dan mengintegrasikan. Hal tersebut dibuktikan dengan hasil tes yang telah dilakukan menunjukkan persentase $0,94 \%$ dari keseluruhan siswa dapat menjawab soal dengan benar dan alasan yang tepat dan kritis.

Pokok bahasan mengenai sifat fisika dan sifat kimia hidrokarbon dengan sub pokok bahasan reaksi-reaksi yang terjadi pada senyawa alkena yang telah diajarkan oleh guru kimia SMA ternyata mampu memunculkan beberapa aspek indikator dari keterampilan berpikir kritis. Beberapa aspek indikator tersebut yaitu indikator a) memberikan penjelasan sederhana dan b) mengemukakan kesimpulan/inferensi. Hal tersebut dibuktikan dengan hasil tes yang telah dilakukan menunjukkan persentase 11,58\% dari keseluruhan siswa dapat menjawab soal dengan benar dan alasan yang tepat dan kritis.

Pokok bahasan mengenai sifat fisika dan sifat kimia hidrokarbon dengan sub pokok bahasan reaksi-reaksi yang terjadi pada senyawa alkuna yang telah diajarkan oleh guru kimia SMA ternyata mampu memunculkan beberapa aspek indikator dari keterampilan berpikir kritis. Materi sifat kimia senyawa alkuna yaitu reaksi-reaksi yang terjadi pada senyawa alkuna yang telah diajarkan oleh guru kimia SMA mampu memunculkan beberapa aspek indikator dari keterampilan berpikir kritis yaitu indikator a) memberikan penjelasan sederhana dan b) mengemukakan kesimpulan/inferensi. Hal tersebut dibuktikan dengan hasil tes yang telah dilakukan menunjukkan persentase 3,57\% dari keseluruhan siswa dapat menjawab soal dengan benar dan alasan yang tepat dan kritis.

Pokok bahasan mengenai sifat fisika dan sifat kimia hidrokarbon dengan sub pokok bahasan identifikasi senyawa hidrokarbon jenuh dan tak jenuh yang telah diajarkan oleh guru ternyata mampu memunculkan beberapa aspek indikator dari keterampilan berpikir kritis. Beberapa aspek indikator tersebut yaitu a) memberikan penjelasan sederhana dan b) membangun keterampilan dasar. Hal tersebut dibuktikan dengan hasil tes yang telah dilakukan menunjukkan persentase $0,75 \%$ dari keseluruhan siswa dapat menjawab soal dengan benar dan alasan yang tepat dan kritis.

Pokok bahasan kegunaan senyawa hidrokarbon yang telah diajarkan oleh guru kimia SMA mampu memunculkan beberapa aspek indikator dari keterampilan berpikir kritis. Beberapa aspek indikator tersebut yaitu a) memberikan penjelasan sederhana, b) 
membangun keterampilan dasar, dan c) memberikan penjelasan lebih lanjut. Hal tersebut dibuktikan dengan hasil tes yang telah dilakukan menunjukkan persentase $14,43 \%$ dari keseluruhan siswa dapat menjawab soal dengan benar dan alasan yang tepat dan kritis.

Keterampilan berpikir kritis dengan indikator memberikan penjelasan sederhana dapat memunculkan keterampilan siswa dalam merumuskan kriteria yang dapat digunakan untuk menentukan kemungkinan jawaban, lalu berdasarkan kriteria tersebut juga dapat digunakan untuk dasar pengambilan suatu keputusan dan penerapan pengetahuan yang dimiliki siswa dalam penyelesaian permasalahan. Prinsip yang telah diterima oleh siswa dalam konsep senyawa hidrokarbon dapat digunakan untuk mengemukakan kesimpulan/inferensi penyelesaian permasalahan yang disajikan. Pemberian penjelasan lebih lanjut mengenai asumsi yang dinyatakan secara tersirat dalam suatu pernyataan atau informasi juga dapat digunakan untuk menyelesaikan permasalahan yang disajikan. Pada tingkat tertinggi yaitu memperkirakan dan mengintegrasikan dapat dimiliki ketika siswa mampu mempertimbangkan suatu asumsi dan meggabungkan kemampuan atau pengetahuan lain untuk membuat keputusan dalam penyelesaian suatu permasalahan yang disajikan.

Keterampilan berpikir kritis siswa dapat diidentifikasi melalui jawaban yang diberikan siswa. Soal yang diberikan merupakan soal pilihan ganda beralasan dan uraian sehingga proses identifikasi dan analisis alur berpikir siswa dalam keterampilan berpikir kritis. Contoh jawaban dari siswa yang menjawab dengan benar pada soal uraian yang berkaitan dengan indikator keterampilan berpikir kritis memperkirakan dan mengintegrasikan disajikan dalam Gambar 2.

\section{Gambar 2 Jawaban Siswa yang Benar dalam Menjawab Soal Uraian pada Indikator Memperkirakan dan Mengintegrasikan}

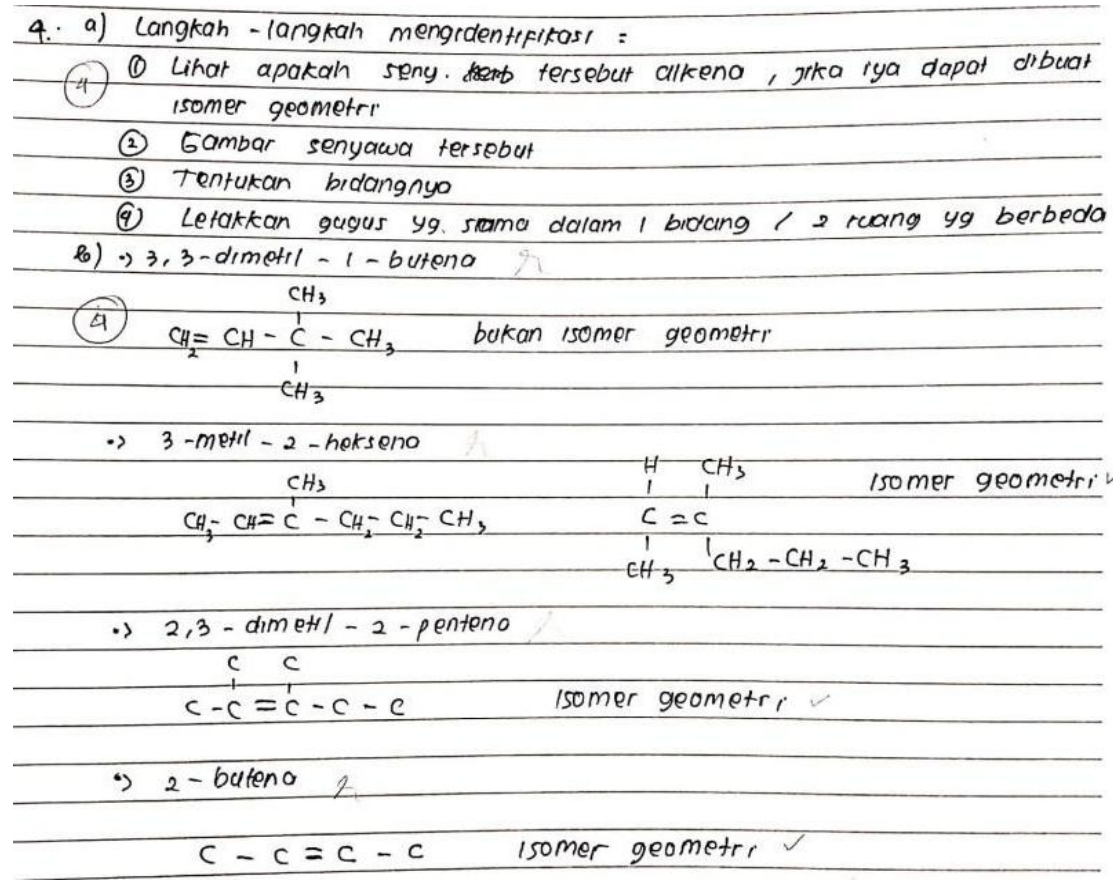


Gambar 2 menunjukkan jawaban siswa pada soal uraian nomor 4a dan 4b, ketika siswa mampu membuat langkah-langkah untuk mengidentifikasi adanya isomer geometri yang dimiliki oleh suatu senyawa alkena maka siswa tersebut memiliki peluang yang besar pula untuk dapat mengidentifikasi suatu senyawa alkena tersebut memiliki isomer geometri atau tidak memiliki isomer geometri berdasarkan kriteria yang telah disusun pada langkahlangkah penentuan isomer geometri.

\section{Simpulan}

Hasil penelitian menunjukkan bahwa materi hidrokarbon yang diajarkan oleh guru mampu memunculkan kemampuan keterampilan berpikir kritis siswa dengan tingkat kemampuan keterampilan berpikir kritis yang masih tergolong sangat rendah dengan ratarata antara lain 1) senyawa karbon organik dan anorganik sebesar 39,10\%, 2) identifikasi dan sumber senyawa karbon sebesar 13,53\%, 3) kekhasan atom karbon sebesar 27,82 \%, 4) tata nama senyawa hidrokarbon sebesar $16,29 \%, 5$ ) isomer senyawa hidrokarbon sebesar $9,62 \%, 6)$ sifat fisika dan kimia senyawa hidrokarbon pada sub pokok bahasan sifat fisika senyawa hidrokarbon sebesar 29,32 \%, sub pokok bahasan reaksi pembakaran senyawa hidrokarbon sebesar 5,71\%, sub pokok bahasan reaksi substitusi senyawa alkana sebesar $0,94 \%$, sub pokok bahasan reaksi senyawa alkena sebesar $11,58 \%$, sub pokok bahasan reaksi senyawa alkuna sebesar 3,57\%, dan sub pokok bahasan identifikasi senyawa hidrokarbon jenuh dan tak jenuh sebesar 0,75\%, dan 7) kegunaan senyawa hidrokarbon sebesar 14,43\%.

Guru perlu memberikan latihan kepada siswa untuk meningkatkan keterampilan berpikir kritis siswa pada materi hidrokarbon sehingga sumbangan materi hidrokarbon terhadap keterampilan berpikir kritis siswa juga dapat ditingkatkan. Sebagian materi yang menyumbang keterampilan berpikir kritis dengan tingkat persentase yang rendah perlu dibelajarkan secara lebih mendalam kepada siswa sehingga menghasilkan sumbangan keterampilan berpikir kritis yang lebih baik.

\section{Daftar Rujukan}

Ennis, R. H. (2011). The nature of critical thinking: An outline of critical thinking dispositions and abilities. University of Illinois, 2(4).

Karim, K., \& Normaya, N. (2015). Kemampuan berpikir kritis siswa dalam pembelajaran dalam pembelajaran matematika dengan menggunakan model jucama di sekolah menengah pertama. EDU-MAT: Jurnal Pendidikan Matematika, 3(1).

Kartimi, L., \& Permanasari, A. (2012). Pengembangan alat ukur berpikir kritis pada konsep senyawa hidrokarbon untuk siswa SMA di Kabupaten Kuningan. Jurnal Pendidikan MIPA, 13(1), 18-25.

OECD. (2012). OECD programme for international student assessment (PISA). Secondary OECD Programme for International Student Assessment (PISA).

Pambudiono, A., Zubaidah, S., \& Mahanal, S. (2013). Perbedaan kemampuan berpikir dan hasil belajar biologi siswa kelas X SMA Negeri 7 Malang berdasarkan jender dengan penerapan strategi jigsaw. Jurnal Pendidikan Hayati, 1(1), 1-10.

Rodliyah, E. A. (2018). Pengembangan instrumen penilaian keterampilan berpikir kritis untuk peserta didik SMA pada materi Hidrokarbon (Doctoral dissertation, Universitas Negeri Malang).

Yustyan, S., Widodo, N., \& Pantiwati, Y. (2016). Peningkatan kemampuan berpikir kritis dengan pembelajaran berbasis scientific approach siswa kelas X SMA Panjura Malang. JPBI (Jurnal Pendidikan Biologi Indonesia), 1(2). 